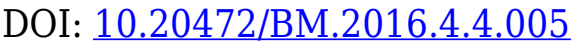

\title{
TECHNICAL EFFICIENCY IN INDIA'S UNORGANISED MANUFACTURING SECTOR: A NON-PARAMETRIC ANALYSIS
}

\author{
JAYANTA SEN, DEBARATI DAS
}

\begin{abstract}
:
Unorganized manufacturing sector accommodates a large portion of workforce who are poor and economically excluded in the developing economies. Indian economy witnessed a rapid economic growth after the adoption of globalization policies in the year 1991. Contribution of unorganized manufacturing sector to the gross domestic product has increased. This sector is generally characterized by low productivity and low efficiency. However increasing importance of this sector makes the efficiency analysis more crucial recently. An attempt has been made in this paper to examine the technical efficiency of India's unorganized manufacturing sector across states. Efficiency levels across different industries/ industry groups are also examined. Data Envelopment Analysis, a non-parametric approach of measuring technical efficiency is used. National Sample Survey Organization (NSSO) data for 1994-95 and 2005-06 have been considered.
\end{abstract}

\section{Keywords:}

Unorganized Manufacturing Sector, Production, Industry, Technical efficiency, Data Envelopment Analysis

JEL Classification: J24, 014, C61

\section{Authors:}

JAYANTA SEN, West Bengal State University, Department of Economics, India, Email: senj123@gmail.com

DEBARATI DAS, West Bengal State University, Department of Economics, India, Email: debarati.das1988@gmail.com

\section{Citation:}

JAYANTA SEN, DEBARATI DAS (2016). Technical Efficiency in India's Unorganised Manufacturing Sector: A Non-parametric Analysis. International Journal of Business and Management, Vol. IV(4), pp. 92-101., 10.20472/BM.2016.4.4.005 


\section{Introduction}

The manufacturing sector plays an important role in boosting the growth of an economy by contributing a major portion to its Gross Domestic Product (GDP). This sector cannot be thought of without recognizing the contribution of its unorganized part. Unorganized manufacturing sector (UMS) not only satisfies consumers' demand by supplying cheaper products but also effectively meets the requirement of intermediate goods by the organized sector. It also generates huge employment for the people who are poor and economically excluded.

Manufacturing sector plays a crucial role in Indian economy. It contributes around 16 percent of the total India's Gross Domestic Product (GDP). Manufacturing sector includes both organized and unorganized sectors. The concept of unorganized sector and its existence was recognised in a study of Keith Hart (1973) and in International Labour Organisation (ILO) Report (1972). Hart (1973) described unorganized sector as an external sector having an autonomous capacity of generating incomes that he observed during his research with rural migrants in Ghana. International Labour Organisation (ILO) considered the enterprise based concept and proposed an international definition of unorganized sector as employment and production taking place in unincorporated and/ or unregistered enterprises. Different Indian organisation like National Sample Survey Organisation (NSSO), Directorate of Employment and Training (DUET), National Commission for Enterprises in the Unorganized Sector (NCEUS) also followed the enterprise based definitions. According to National Accounts Statistics (NAS), India, unorganized sector not only includes unincorporated proprietary and partnership enterprises but also enterprises run by Cooperative Societies, Trust, Private and Limited Companies. Unorganized manufacturing sector (UMS) in India includes all manufacture enterprises those are not registered under $2 \mathrm{~m}$ (i) and $2 \mathrm{~m}$ (ii) of Factories Act , 1948 (India).

Unorganized manufacturing sector (UMS) contributes more than one-third of total contribution of manufacturing sector in India's GDP. This sector absorbs around 22.9 percent of total male workers and 60.2 percent of total female workers in unorganized sector. UMS, an important part of unorganized sector in India that not only acts as a source of livelihood for a huge number of low skilled workforce but also act as a catalyst to economic growth.

After the economic reforms policies adopted by the Indian economy in the year 1991, trade and manufacturing sector have experienced structural changes through removal of restrictions on export, import and investment (foreign and domestic) in order to achieve economic efficiency. The entire economy was thrown into a highly competitive global world where demand for skilled workers has been generated. The size of the unorganized 
sector has grown substantially as unskilled or semi-skilled workforce tended towards unorganized sector for their livelihood options. With rising labour force, the role of unorganized manufacturing sector has become more prominent towards employment generation. This sector has also an enormous contribution to the country's Gross Domestic Product (GDP). Hence exploring this sector more intensively has become highly interesting to the Researchers in the recent era. Studies are available on different perspectives of unorganized manufacturing sector in India (Shah,1998; Nagraj, 1999; Golder, et al, 1999; Kundu, et.al 2001; Puspagadan, 2004; Aggarwal, et.al 2013; Jena 2013). Kundu, et.al (2001) found that employment size in Own Account Manufacturing Enterprises (OAMEs) and Non-Directory Manufacturing Enterprises (DMEs) have increased in the early eighties, but then declined later during the later period of that decade. Jena (2013) observed that the share of female labour force to the total employment in UMS has increased during the period 1994-95 to 2005-06. Aggarwal, et.al (2013) has examined the employment scenario in UMS in Uttar Pradesh and he argued on the need for more female workers of the state to be engaged in the sector. Studies on production and efficiency of UMS are very few (Nataranjan et al, 2007; Bairagya, 2009; Mukherjee 2009; Das and Sen, 2013). To the best of my knowledge, research was almost undone to examine the technical efficiency of India's Unorganized manufacturing sector at the industry level.

\section{Objective of the Study}

With increasing importance of Unorganized manufacturing sector, the efficiency analysis has become more interesting to the Researchers and Policymakers especially in the context of highly populated and under-developed economy like India. Attempt has thus been made in this paper to examine the degree of technical efficiency in unorganized manufacturing sector in India and its major states. The major objectives of this study are:

- To estimate the technical efficiency of different types of enterprises of Unorganized manufacturing sector in India and its major constituent states.

- To examine the efficiency levels across industries/ industry groups of UMS

Technical efficiency is estimated through a non-parametric method known as Data Envelopment Analysis (DEA).

\section{Methodology}

\section{Measuring Technical Efficiency: Data Envelopment Analysis (DEA)}

The technical efficiency of a firm is a comparative measure which indicates how well it actually processes inputs to achieve its output as compared to its maximum potential for doing so represented by its production possibility frontier (Farrell, 1957). A firm will be recognized as relatively inefficient if it performs below the frontier. Technical efficiency may be input-oriented or output-oriented. Input-oriented technical efficiency is associated 
with minimal input usage to have the same level of output. Output-oriented technical efficiency emphasizes on expanding output with same level of input usage. For the purpose of measuring technical efficiency, Data Envelopment Analysis (DEA), a nonparametric approach is broadly used. DEA based on constant returns to scale is generally known as CCR Model (Charnes, Cooper and Rhodes, 1978). When it (DEA) considers variable returns to scale it is known as BCC Model (Banker, Charnes and Cooper, 1989). Data Envelopment Analysis (DEA) is based on a mathematical structure as:

Objective: $\operatorname{Min} \theta_{r}$

Subject to

$$
\begin{aligned}
& \sum_{j=1}^{n} \mu_{j} y_{i j} \geq y_{i r} \\
& \sum_{j=1}^{n} \mu_{j} x_{i j} \leq \theta_{r} x_{k r} \\
& \mu_{j} \geq 0
\end{aligned}
$$

Suppose there are ' $n$ ' organizations that produce's' different outputs by using ' $t$ ' different inputs. $\mu_{j}$ are the weights applied across $\mathrm{n}$ organizations. Here $\theta$ is the efficiency score that is expressed as the potential to reduce the quantities of inputs used in producing given level of outputs. ' $y_{i r}$ ' denotes the observed amount of output $i$ for $\mathrm{r}^{\text {th }}$ organization and ' $x_{k r}$ ' denotes the observed amount of inputs $k$ used by organization $r$. The objective is therefore to minimize the input usage of the $r^{\text {th }}$ industry to produce the same level of output (equation1). The efficiency score for the $r^{\text {th }}$ organization is denoted by $\theta_{r}$, which satisfies the three sets of constraints mentioned above. The first constraint (equation2) depicts that the weighted average of the other organizations must produce at least as much as output as does the $r^{\text {th }}$ organization, with not using more of any input than does the $r^{\text {th }}$ industry (the second constraint, i.e. equation 3). The third constraint assumes the weights to be either zero or positive. When the problem is solved for the $\mathrm{r}^{\text {th }}$ organization, these weights let to determine the most efficient technique of producing the organization r's output.

The value of $\theta$ varies from zero to one. High value of $\theta$ corresponds to high efficiency score, while, the value equal to one implies perfect efficiency for the producing unit. There are several applications of this method in Banks (Sharma, 2012), Ivorian manufacturing industry (Chapelle, et.al. 2005), Sugar industry (Kumar, 2012), and many others. In this study the input oriented DEA model assuming constant returns to scale has been applied to measure the relative efficiency of unorganized manufacturing Sector for the periods 1994-95 and 2005-06. 


\section{Estimates}

Technical efficiency parameter is estimated in order to judge the operational performance of India's unorganized manufacturing sector along with different types of enterprises. Fifteen major Indian states have been considered in our analysis. Efficiency parameters across different industries/ industry groups are also estimated. The Unorganized manufacturing sector has been classified into thirteen Industries/Industry Groups as mentioned in Table 1. Three types of enterprises such as, Own Account Manufacturing Enterprise (OAME), Non-Directory Manufacturing Enterprise (NDME) and Directory Manufacturing Enterprise (DME) are considered. The OAMEs run without an hired worker, whereas NDMEs run with less than six workers. DMEs deal with more than six workers but less than ten workers.

Table1: Classification of Unorganized Manufacturing Sector: Industry/Industry Groups

\begin{tabular}{|c|c|}
\hline Industry/Industrial Groups & Products Included \\
\hline Industry1 & Food manufacturing and Beverage, tobacco \\
\hline Industry 2 & Cotton/ Wool/ Jute Textile/ Wearing Apparels \\
\hline Industry 3 & Leather and Leather Products \\
\hline Industry 4 & Wood/ Wood Products \\
\hline Industry 5 & Paper and Printing Record Media \\
\hline Industry 6 & Chemical Products \\
\hline Industry 7 & Non-Metallic \\
\hline Industry 8 & Bubber, Plastic, Petrol and Alloys \\
\hline Industry 9 & Fabricated Metal except equipment \\
\hline Industry 10 & Machinery Equipment except Transport \\
\hline Industry 11 & Transport Related Goods \\
\hline Industry 12 & Other Manufacturing and Repairing and Recycling \\
\hline Industry 13 &
\end{tabular}

Source: National Sample Survey Organization (NSSO) Data

In order to estimate the relative efficiency of unorganized manufacturing sector in India, gross value added is taken as representative output. Number of workers and fixed asset owned represents two inputs. The number of workers includes the full-time, part-time, working owners and hired workers. The owned fixed assets include the land, buildings and other constructions, plant and machinery, transport equipments tools and other fixed assets that have economic existence more than a year from the date of acquisition (Rani and Unni, 2004). We have used National Sample Survey Organization (NSSO) data on unorganized manufacturing sector for 1994-95 and 2005-06.

\section{Technical Efficiency in Unorganized Manufacturing Sector}

Unorganized manufacturing sector in India has undergone a structural change during the period of economic reforms. The number of enterprises has increased from 14.54 million in 1994-95 to 17.07 million in 2005-06 (Table 2). Highest increase is observed in case of 
Own Account Manufacturing Enterprises (OAMEs) followed by Non-Directory Manufacturing Enterprises (NDMEs) and Directory Manufacturing Enterprise (DMEs). Number of workers employed in this sector has increased about 3.2 million during the period. DMEs exhibit the highest employment growth (about 23\%). OAMEs absorb about 24 million workers in 2005-06. All the enterprises show more than 100 percent increase in gross value addition during the period and DMEs are more pronounced in this regard.

Table 2: Unorganized Manufacturing Sector in India: Compositional Change

\begin{tabular}{|c|c|c|c|}
\hline Variables & 1994-95 & 2005-06 & Growth (\%) \\
\hline \multicolumn{3}{|c|}{ Enterprises (in millions) } & \\
\hline OAME & 12.26 & 14.61 & 19.19 \\
\hline NDME & 1.60 & 1.77 & 10.64 \\
\hline DME & 0.65 & 0.68 & 5.79 \\
\hline All enterprise & 14.51 & 17.07 & 17.65 \\
\hline \multicolumn{3}{|c|}{ Workers (in millions) } & \\
\hline OAME & 22.66 & 23.69 & 4.52 \\
\hline NDME & 4.89 & 5.78 & 18.29 \\
\hline DME & 5.65 & 6.97 & 23.36 \\
\hline All enterprise & 3320 & 3644 & 9.76 \\
\hline \multicolumn{3}{|c|}{ Gross Value Added (GVA) (Rupees. '000) } & \\
\hline OAME & 1378200 & 2806100 & 103.61 \\
\hline NDME & 765800 & 2112000 & 175.79 \\
\hline DME & 1083400 & 3840500 & 254.49 \\
\hline All enterprise & 3227400 & 8758600 & 171.38 \\
\hline
\end{tabular}

Source: Authors' Calculation based on NSSO Data

The technical efficiency score $(\theta)$ attained by different enterprises of unorganized manufacturing sector (UMS) across Indian states is presented in Table 3 . The overall mean technical efficiency score has declined from 0.834 in 1994-05 to 0.797 in 2005-06 in India during the period. Though mean technical efficiency has declined in case of OAMEs and DMEs, it has sharply increased in case of NDMEs. Perfect efficiency level is observed in three states in 2005-06 (Haryana, Maharashtra and Assam). Haryana has consistently maintained the perfect efficiency score over the period. Assam, Gujarat, Haryana, Madhya Pradesh, Orissa, Rajasthan, Tamil Nadu and West Bengal have shown higher level of efficiency in both the periods. A decline in technical efficiency is observed in Andhra Pradesh, Bihar, Kerala, Madhya Pradesh, Punjab, Rajasthan, Tamil Nadu and West Bengal.

In almost all the states except Maharashtra and West Bengal, the efficiency level of OAMEs of Unorganized manufacturing sector (UMS) has declined. The technical efficiency score in case of OAMEs in Madhya Pradesh has dropped drastically from 0.851 to 0.282 which indicates 71.8 percent loss of efficiency in input utilization in 2005-06. The NDMEs of Assam, Bihar and Maharashtra have achieved perfect relative efficiency in 
2005-06. An increase in the efficiency level of NDMEs is observed in Uttar Pradesh and Assam. DMEs of Bihar and Madhya Pradesh exhibit highest efficiency score in 2005-06. Assam and Haryana has failed to maintain the perfect efficiency level. Efficiency score in Karnataka, Bihar, Madhya Pradesh and Orissa has increased in case of DMEs. Efficiency level of OAMEs and DMEs has declined in Gujarat, Kerala, Punjab, Rajasthan, and Tamil Nadu. DMEs of six states show higher technical efficiency score compared to overall mean technical efficiency level in 2005-06. Through lowest efficiency was noticed in DMEs of Madhya Pradesh in 1994-95, a remarkable improvement is observed in 200505 (Table 3).

Table 3. Technical Efficiency in Unorganized Manufacturing Sector in Indian States

\begin{tabular}{|c|c|c|c|c|c|c|c|c|}
\hline & \multicolumn{2}{|c}{ OAME } & \multicolumn{2}{c|}{ NDME } & \multicolumn{2}{c|}{ DME } & \multicolumn{2}{c|}{ All Enterprise } \\
\hline STATES & $\begin{array}{c}\mathbf{1 9 9 4 -} \\
\mathbf{9 5}\end{array}$ & $\begin{array}{c}\mathbf{2 0 0 5 -} \\
\mathbf{0 6}\end{array}$ & $\begin{array}{c}\mathbf{1 9 9 4 -} \\
\mathbf{9 5}\end{array}$ & $\begin{array}{c}\mathbf{2 0 0 5 -} \\
\mathbf{0 6}\end{array}$ & $\mathbf{1 9 9 4 - 9 5}$ & $\begin{array}{c}\mathbf{2 0 0 5 -} \\
\mathbf{0 6}\end{array}$ & $\begin{array}{c}\mathbf{1 9 9 4 -} \\
\mathbf{9 5}\end{array}$ & $\mathbf{2 0 0 5 - 0 6}$ \\
\hline $\begin{array}{c}\text { Andhra } \\
\text { Pradesh }\end{array}$ & 0.841 & 0.461 & 0.492 & 0.488 & 0.515 & 0.085 & 0.718 & 0.596 \\
\hline Assam & 0.943 & 0.697 & 0.450 & 1.000 & 1.000 & 0.457 & 0.801 & 1.000 \\
\hline Bihar & 0.839 & 0.805 & 0.574 & 1.000 & 0.631 & 1.000 & 0.764 & 0.548 \\
\hline Gujarat & 0.942 & 0.580 & 0.692 & 0.694 & 0.797 & 0.454 & 0.887 & 0.810 \\
\hline Haryana & 1.000 & 0.847 & 0.952 & 0.814 & 1.000 & 0.661 & 1.000 & 1.000 \\
\hline Karnataka & 0.762 & 0.401 & 0.533 & 0.714 & 0.452 & 0.512 & 0.697 & 0.832 \\
\hline Kerala & 0.879 & 0.462 & 0.529 & 0.686 & 0.527 & 0.361 & 0.785 & 0.633 \\
\hline $\begin{array}{c}\text { Madhya } \\
\text { Pradesh }\end{array}$ & 0.851 & 0.282 & 1.000 & 0.984 & 0.235 & 1.000 & 1.000 & 0.711 \\
\hline Maharashtra & 0.940 & 1.000 & 0.825 & 1.000 & 0.271 & 0.635 & 0.724 & 1.000 \\
\hline Orissa & 0.793 & 0.616 & 0.425 & 0.560 & 0.340 & 0.512 & 0.620 & 0.898 \\
\hline Punjab & 1.000 & 0.747 & 0.729 & 0.747 & 0.751 & 0.492 & 0.832 & 0.775 \\
\hline Rajasthan & 0.851 & 0.617 & 0.678 & 0.787 & 0.773 & 0.464 & 1.000 & 0.776 \\
\hline Tamil Nadu & 0.954 & 0.493 & 0.516 & 0.569 & 0.771 & 0.371 & 0.884 & 0.674 \\
\hline Uttar Pradesh & 0.810 & 0.767 & 0.460 & 0.911 & 0.779 & 0.795 & 0.792 & 0.942 \\
\hline West Bengal & 1.000 & 1.000 & 0.704 & 0.602 & 0.737 & 0.648 & 1.000 & 0.754 \\
\hline $\begin{array}{c}\text { Mean } \\
\text { Technical } \\
\text { Efficiency }\end{array}$ & $\mathbf{0 . 8 9 4}$ & $\mathbf{0 . 6 5 2}$ & $\mathbf{0 . 6 3 7}$ & $\mathbf{0 . 7 7 0}$ & $\mathbf{0 . 6 3 8}$ & $\mathbf{0 . 5 6 3}$ & $\mathbf{0 . 8 3 4}$ & $\mathbf{0 . 7 9 7}$ \\
\hline
\end{tabular}

Source: Authors' Calculation based on NSSO Data

OAME: Own Account Manufacturing Enterprise, NDME: Non-Directory Manufacturing Enterprise, DME: Directory Manufacturing Enterprise

\section{Technical Efficiency across Industries/Industry Groups of UMS}

Technical efficiency of different industries/industry groups of Unorganized manufacturing sector has been examined for different types of enterprises (Table 4). The mean technical efficiency has declined marginally from 77.8 percent to 76.5 percent over the years 19942006. Leather industry and Basic Metal and Alloy industry has achieved perfect efficiency consistently over the years. The Non-metallic and Fabricated Metal industry have 
significantly increased their efficiency levels. The industry group of Rubber, Plastic, Petroleum, Coal and Nuclear products has deviated from perfect efficiency level over the period.

Table 4: Technical Efficiency of UMS across Industries/ Industry groups

\begin{tabular}{|c|c|c|c|c|c|c|c|c|}
\hline \multirow{2}{*}{$\begin{array}{c}\text { Industry/Industry } \\
\text { Groups }\end{array}$} & \multicolumn{2}{|c|}{ OAME } & \multicolumn{2}{c|}{ NDME } & \multicolumn{2}{c|}{ DME } & \multicolumn{2}{c|}{ ALL } \\
\cline { 2 - 8 } & $\begin{array}{c}\mathbf{1 9 9 4 -} \\
\mathbf{9 5}\end{array}$ & $\begin{array}{c}\mathbf{2 0 0 5 -} \\
\mathbf{0 6}\end{array}$ & $\begin{array}{c}\mathbf{1 9 9 4 -} \\
\mathbf{9 5}\end{array}$ & $\begin{array}{c}\mathbf{2 0 0 5 -} \\
\mathbf{0 6}\end{array}$ & $\begin{array}{c}\mathbf{1 9 9 4} \\
\mathbf{9 5}\end{array}$ & $\begin{array}{c}\mathbf{2 0 0 5 -} \\
\mathbf{0 6}\end{array}$ & $\begin{array}{c}\mathbf{1 9 9 4 -} \\
\mathbf{9 5}\end{array}$ & $\begin{array}{c}\mathbf{2 0 0 5 -} \\
\mathbf{0 6}\end{array}$ \\
\hline $\begin{array}{c}\text { Food Processing and } \\
\text { Beverage, tobacco }\end{array}$ & 0.730 & 0.580 & 0.500 & 0.755 & 0.703 & 0.487 & 0.570 & 0.597 \\
\hline $\begin{array}{c}\text { Cotton/ Wool/ Jute } \\
\text { Textile/ Wearing } \\
\text { Apparels }\end{array}$ & 0.761 & 0.527 & 0.465 & 0.630 & 0.501 & 0.587 & 0.514 & 0.546 \\
\hline $\begin{array}{c}\text { Leather and Leather } \\
\text { Products }\end{array}$ & 0.896 & 1.000 & 1.000 & 0.962 & 1.000 & 1.000 & 1.000 & 1.000 \\
\hline Wood/ Wood Products & 0.305 & 1.000 & 1.000 & 0.673 & 0.891 & 0.516 & 0.793 & 0.678 \\
\hline $\begin{array}{c}\text { Paper and Printing } \\
\text { Record Media }\end{array}$ & 1.000 & 0.641 & 0.568 & 0.762 & 0.648 & 0.532 & 0.642 & 0.642 \\
\hline $\begin{array}{c}\text { Rubber, Plastic, } \\
\text { Petroleum, Coal and } \\
\text { Nuclear Products }\end{array}$ & 0.319 & 0.804 & 0.761 & 0.892 & 0.775 & 0.581 & 1.000 & 0.739 \\
\hline Chemical Products & 0.656 & 0.387 & 0.492 & 0.952 & 0.718 & 0.529 & 0.567 & 0.567 \\
\hline Non-Metallic & 1.000 & 0.947 & 0.488 & 0.788 & 0.767 & 0.702 & 0.743 & 0.889 \\
\hline Basic Metal and Alloys & 0.372 & 1.000 & 0.675 & 0.704 & 1.000 & 1.000 & 1.000 & 1.000 \\
\hline $\begin{array}{c}\text { Fabricated Metal } \\
\text { except equipment }\end{array}$ & 0.709 & 0.830 & 0.675 & 0.92 & 0.670 & 1.000 & 0.756 & 1.000 \\
\hline $\begin{array}{c}\text { Machinery Equipment } \\
\text { except Transport }\end{array}$ & 0.613 & 0.386 & 0.563 & 0.877 & 0.935 & 1.000 & 0.750 & 0.776 \\
\hline $\begin{array}{c}\text { Transport Related } \\
\text { Goods }\end{array}$ & 0.565 & 0.881 & 0.893 & 0.904 & 0.728 & 0.457 & 0.976 & 0.657 \\
\hline $\begin{array}{c}\text { Other Manufacturing } \\
\text { and Repairing and } \\
\text { Recycling }\end{array}$ & 1.000 & 0.564 & 0.658 & 1.000 & 0.731 & 0.608 & 0.805 & 0.861 \\
\hline $\begin{array}{c}\text { Mean Technical } \\
\text { Efficiency }\end{array}$ & 0.687 & 0.734 & 0.672 & 0.832 & 0.774 & 0.692 & 0.778 & 0.765 \\
\hline
\end{tabular}

Source: Authors' Calculation based on NSSO Data

OAME: Own Account Manufacturing Enterprise, NDME: Non-Directory Manufacturing Enterprise, DME: Directory Manufacturing Enterprise

The mean technical efficiency of OAMEs and NDMEs of different industry/ industry groups show rising trend. OAMEs of seven industries/ industry groups exhibit a decline in efficiency level. In case of OAMEs of Leather, Wood, Basic Metal and Alloy industries have achieved perfect technical efficiency levels during the period under consideration. NDMEs of Leather industry and Wood industry have experienced a deviation from their perfect efficiency levels. DMEs have come across with a decline in their efficiency levels from 77.4 percent to 69.2 percent over the years. Leather, Basic Metal and Alloy, Fabricated Metal and Machinery Equipment have consistently maintained perfect 
efficiency levels in 2005-06. DMEs of eight industries have shown a decline in efficiency scores.

\section{Concluding Remarks}

The analysis of technical efficiency in Unorganized manufacturing sector (UMS) in India highlights the operational performance of small and micro enterprises. There has been a growth of UMS in terms of employment generation and gross value addition which is accompanied by the slowdown in technical efficiency during the period. The overall mean technical efficiency of Unorganized manufacturing sector measured across states or across industries/industry Groups reveals a declining trend over the years. Mean technical efficiency of OAMEs and DMEs has fallen while that of NDMEs has risen. Perfect technical efficiency level is observed in Assam, Haryana and Maharashtra in 2005-06. Rubber, Plastic, Petroleum, Coal, Nuclear Product industry and transport related goods industries have experienced a significant fall in their efficiency levels. Leather industry and Basic Metal and Alloy industry have maintained highest efficiency levels consistently over the years. A wide variation of efficiency levels among industries/ industry groups of UMS is observed. Technical efficiency score would be useful to identify the industries as well as enterprises those are lagging behind in terms of their performance.

Special attention and co-operation from the Government is needed to boost up the operational performance of different enterprises of unorganized manufacturing sector so that they can raise their efficiency level and add up more to their contributions to GDP of our economy. The coverage of banking credit facilities at lower interest rates should be extended so that the enterprises may be able to increase their capital strength. Necessary action should be taken to bring these enterprises under some formal recognition. Moreover, Public-Private Partnership (PPP) model might be structured in order to channelize the products of this sector more export oriented. The employees of unorganized manufacturing sector should be motivated to enhance their productivity level by providing them vocational training, social security benefits and insurance facilities.

\section{References}

Aggarwal, H, G.; Hima, and Sengupta, J (2013). Unorganised Manufacturing Sector in Uttar Pradesh: An Empirical Study. International Journal of Innovative Research and Development. Vol 2, Issue 12. Dec, 2013 (Special Issue).

Banker, R.D.;Charnes, A., and Cooper, W.W. (1984). Some Models for Estimating Technical and Scale Inefficiencies in Data Envelopment Analysis. Management Science 30. pp.1078-1092

Chapelle, K. and Plane, P (2005). Productive Efficiency in the Ivorian Manufacturing Sector: An Exploratory Study Using a Data Envelopment Analysis Approach. The Developing Economies, 43(4), 450-71. 
Charners, A.; Cooper, W.W. and Rhodes, E. (1978). Measuring the Efficiency of Decision Making Unit. European Journal of Operations Research, 2, 429-449.

Das, D. and Sen, J. (2013). Technical Efficiency in Unorganised Manufacturing Sector: An Analysis in terms of DEA. Indian Economic Journal, Special Issue, ISSN: 0019-4662.

Sharma, A. K.; Sharma, D. and Barua, M.K.Efficiency and Productivity of Indian Banks: An Application of Data Envelopment Analysis and Tobit Regression. National Conference on Emerging challenges for sustainable Business 2012.

Farrell, M.J. (1957). The measurement of productive efficiency. Journal of Royal Statistical Society A (General), 120(2), 253-281.

Golder, B. and Mitra, A. (1999). Productivity Growth in Informal Sector in India. Paper presented at the Workshop on Measurement of Productivity in India, July, 1999.

Bairagya, I. (2009). Informal Sector in India: Contribution, Growth and Efficiency. Paper Prepared for the Special IARIW-SAIM Conference on "Measuring the Informal Economy in Developing Countries". [Online]. Availablefromhttp://www.iariw.org/papers/2009/8a\%20Bairagya.pdf.

Jena, N. (2013). Changing Employment Patterns in Informal Manufacturing Sector in India, in Prakasan, Seepana (ed.). Informal Employment in India: Issues and Challenges", Bookwell Publications, New Delhi.

Kumar, S. and Arora, N. (2012). Evaluation of Technical Efficiency in Indian Sugar Industry: An Application of Full Cumulative Data Envelopment Analysis. Eurasian Journal of Business and Economics. 2012, 5 (9), 57-78.

Kundu, A.; Arora, L.N. and Lal, S. (2001). Growth Dynamics of Informal Manufacturing Sector in Urban India: An analysis of Independencies, in Kundu, Amitabh and Alakh N Sharma (eds.), Informal Sector in India: Perspectives and Policies, IHD and IAMR, New Delhi.

Mukherjee, D. (2009). Informal Sector in Indian Economy: The Way Ahead, (ed.). Rawat Publications, New Delhi, 2009.

Nagraj, R. (1999). Productivity Measurement in Indian Manufacturing Sector. Paper presented at the Workshop on the Measurement of Productivity in India, NPC, July, 1990.

Puspangadan. K. and Shanta, N. (2004).Growth and Efficiency in Informal Sector in India: A NonParametric Analysis. Labour and Development, Vol. 10, No. 1.

Rani, U. and Unni, J. (Oct. 9 - 15, 2004). Unorganised and Organised Manufacturing in India: Potential for Employment Generating Growth. Economic and Political Weekly. Vol. 39, No. 41 (Oct. 9-15, 2004), pp. 4568-4580.

Rajesh Raj, S.N. (2007). Technical Efficiency in the Informal Manufacturing Enterprises: Firm level evidence from an Indian state. Download from http://mpra.ub.uni-muenchen.de/7816/. (MPRA Paper No. 7816 posted 19. March 2008 04:40 UTC).

Shah, A. (1998). Scalar Linkages in Industries: Implications for Productivity and Employment, Indian Journal of Labour Economics, Vol. 41, No. 3. 